\section{AB0205 UNUSUAL AETIOLOGY OF ERYTHEMA NODOSUM, ARTHRITIS, AND PLEURAL EFFUSION}

U Steiger, M Weber, H Gerber. Department of Rheumatology and Rehabilitation, Triemli Hospital, CH - 8063 Zürich, Switzerland

\subsection{6/annrheumdis-2001.716}

Background Association of erythema nodosum with giardia lamblia infection is only known for a few adult cases in the literature. ${ }^{1}$ Several case reports discuss reactive arthritis or sacroiliitis with giardiasis. ${ }^{2}$ Allergies and other immunological features such as pleural eosinophilic effusion have occasionally been reported as well.

Objectives A 36-year-old male refugee from Sri Lanka was referred to our outpatient department for erythema nodosum and history of arthralgia of large and medium-size joints and low back pain not fully responsive to NSAID. He also had symptoms such as low grade fever, conjunctival injection, and headaches. He complained of a slight weight loss. Family history and system review was unremarkable except for intermittent chronic eye inflammation with itching, later classified as nodular episcleritic lesions. There were no gastrointestinal complaints.

Methods Clinical examination revealed erythema nodosum and pleural effusion, but no synovialitis.

Laboratory analysis showed mild inflammatory reaction with normal eosinophil count, no complement consumption nor significant auto-antibody titer. Serum IgE titer was high. Threephase bone scintigraphy and $\mathrm{x}$-ray of the sacroiliacal joints were normal. Chest x-ray showed a pleural effusion.

Because of life style and origin of the patient, we ordered a stool sample examination, which was full of giardia lamblia.

Results The prescribed metronidazole regimen was not taken for compliance problems.

Five months later he was again referred for erythema nodosum and arthritis with swelling of ankle, wrist, knee and MCP joints. Chest x-ray revealed pleural effusion as before. Stool samples again showed giardia infestation with unchanged laboratory analyses. After a five days course of metronidazole $250 \mathrm{mg}$ t.i.d., joint symptoms diminished dramatically, and erythema nodosum vanished.

Conclusion Giardia lamblia infection typically presents with abdominal symptoms or malabsorption syndrome, some patients develop low grade fever and headaches. Hypersensitivity symptoms such as pleural effusion, reactive arthritis and erythema nodosum are very rarely reported. Diagnosis is confirmed by the good response of the joint symptoms to antiparasitic therapy.

The presented case of relapsing erythema nodosum and arthritis and pleural effusion documents for the first time in the literature the coincidence of these three rare complications of giardiasis.

\section{REFERENCES}

1 Giordano N, Fioravanti A, Mariani A, Marcolongo R. Erythema nodosum and giardia intestinalis. Clin Rheumatol. 1985:4:481-3

2 Tupchong $M$, Simor A, Dewar C. Beaver fever ? a rare cause of reactive arthritis. I Rheumatol. 1999;26:2701-2

\section{AB0206 INVESTIGATION OF THE INDUCIBILITY OF RETROVIRUSES FROM RHEUMATOID ARTHRITIS SYNOVIAL FIBROBLASTS (RA-SF) AND RA-SYNOVIAL FLUID CELLS (RA-SFC)}

${ }^{1} \mathrm{CA}$ Seemayer, ${ }^{2} \mathrm{SA}$ Kolb, ${ }^{3} \mathrm{~J}$ Böni, ${ }^{1} \mathrm{M}$ Neidhart, ${ }^{4} \mathrm{~B}$ Simmen, ${ }^{1} \mathrm{RE}$ Gay, ${ }^{1} \mathrm{BA}$ Michel, 3J Schüpbach, 'S Gay. 'Center Exp Rheum; ' Electron Microsc Pathol, University Hospital:

${ }^{3}$ Nat Swiss Center Retrov, University; ${ }^{4}$ Orth Surg, Schulthess Clin, Zürich, Switzerland

10.1136/annrheumdis-2001.717

\section{Background}

Objectives In many investigations virus like particles (VLP) and especially type- $\mathrm{C}$ retroviruses could be activated from tumour cells in culture after stimulation with DNA damaging agents. Coculture with H9 cells, a lymphatic cell line, has been successfully used to isolate exogenous human retroviruses such as HTLV and HRV-5. The aim of this study was to induce potentially hidden retroviruses from cell cultures from RA patients and to analyse for VLP and reverse transcriptase (RT)-activity.

Methods Rheumatoid arthritis synovial fibroblasts (RA-SF) were derived from synovial biopsies and synovial fluid cells from RA synovial fluids. Normal skin fibroblasts served as controls for the RA-SF and SFC from arthritis urica as well as unclassified oligoarthritis for the RA-SFC. As positive control we used baby hamster kidney cells, murine mast cells and pig fibroblasts, which produce endogenous retroviruses. Subconfluent RA-SF and controls were incubated with azacytidin (AzaC: $2 \mu \mathrm{g} / \mathrm{ml}$ for $24 \mathrm{~h}$ ), bromodeoxyuridine (BUDR: $25 \mu \mathrm{g} / \mathrm{ml}$ for $24 \mathrm{~h}$ ) or irradiated with 2 or 8 Gy X-rays, respectively. Supernatants of cell cultures were taken after $24 \mathrm{~h}$ or $48 \mathrm{~h}$ and analysed for RT-activity by the product enhanced reverse transcriptase (PERT)-assay. The cells were harvested on days 2-6 without trypsinization, fixed in glutaraldehyde and prepared for electron microscopy. Furthermore, RA-SF and RA-SFC were co-cultured with H9 cells for more than 3 weeks, and the supernatant was collected every 3-4 days and analysed by the PERT-assay.

Results In the virus induction and co-culture experiments, no evidence for RT-activity could be detected. In contrast, the positive controls including supernatants of cell cultures from baby hamster kidney cells, murine mast cells and pig fibroblasts revealed a strong positive RT-activity. The electron microscopical investigation of the AzaC, BUDR treated or irradiated cells did not reveal VLP.

Conclusion The current investigation does not support the involvement of infectious retroviruses in RA, but cannot exclude a role of exogenous and/or endogenous retroviruses, or the involvement of endogenous retroviral elements in the pathogenesis of RA.

C. A. Seemayer supported by the DAAD and by the Theodor und Ida Herzog-Egli Stiftung, all others by their institutions.

\section{OP0105 A COMPARISON OF POST STREPTOCOCCAL REACTIVE ARTHRITIS SUBGROUPS BASED ON ASO/ANTIDNASE-B RATIOS; A THREE YEAR INCEPTION COHORT STUDY}

${ }^{1} \mathrm{TL}$ Jansen, ${ }^{1} \mathrm{PM}$ Houtman, ${ }^{1} \mathrm{EN}$ Griep, ${ }^{1} \mathrm{GA}$ Bruyn, ${ }^{2} \mathrm{AM}$ Elsacker-Niele. ${ }^{1}$ Rheumatology; ${ }^{2}$ Microbiology, Lab.vd. Volksgezondheid, Leeuwarden, Netherlands

10.1136/annrheumdis-2001.718

Background Last decade a resurgence of post streptococcal reactive arthritis (PSRA) is observed in the Netherlands. As throat cultures often remain negative, dicrimination between cases due to group A streptococci (GAS) versus non-group A streptococci 